\title{
USF1 w patologii wybranych jednostek chorobowych
}

\section{USF1 in the pathology of selected diseases}

\author{
Joanna Iwanicka ${ }^{\bowtie}$, Iwona Żak \\ Śląski Uniwersytet Medyczny w Katowicach, Zakład Biochemii i Genetyki Medycznej, ul. Medyków 18, 40-752 Katowice \\ $\triangle$ jiwanicka@sum.edu.pl
}

\begin{abstract}
USF1 belongs to a family of transcription factors characterized by highly conserved helix-loop-helix and leucine zipper domains. The USF1 polypeptide is encoded by the USF1 gene located in the long arm of chromosome 1 . The USF1 protein can form homodimers or heterodimers with the USF2 polypeptide. Being a subunit of the dimeric upstream transcription factor, USF1 plays multiple roles in the transcription regulation of many genes, which includes the E-box motif in the promoter region. The activation of gene transcription depends on the integrity of the b-HLH-LZ dimerized domains of USF with the region of DNA. The expression of the USF1 gene and the binding abilities of the protein transcription factor to the promoter region of a target gene is regulated by phosphorylation and methylation processes. The
\end{abstract}

transcription factor USF1 regulates the expression of numerous genes involved, e.g. in the cell cycle, cellular proliferation, cellular ageing, stress and immune response, carcinogenesis, and lipid and carbohydrate metabolism. Moreover, the genetic variants of USF1 can be associated, e.g. with changed levels of serum lipids, glucose and specific markers of carcinogenesis. Among the studied polymorphisms of USF1 a group of genetic variants can be identified, which are associated with risk factors for cardiovascular events. USF1 is also one of the main factors for coronary artery disease, metabolic syndrome, diabetes type II, and familial combined hyperlipidemia.

Keywords: USF1; polymorphism; coronary artery disease; diabetes mellitus type II; cancers.

\begin{abstract}
ABSTRAKT
USF1 należy do rodziny czynników transkrypcyjnych charakteryzujących się obecnością wysoce konserwatywnych domen: helisa-pętla-helisa oraz zamka leucynowego. USF1 kodowany jest przez gen $U S F 1$, którego locus znajduje się na ramieniu długim chromosomu 1. Białko USF1 może tworzyć homodimery lub heterodimery z polipeptydem USF2. Będąc podjednostką dimerycznego czynnika transkrypcyjnego, USF1 reguluje ekspresję wielu genów cechujących się obecnością motywu E-box w obrębie regionu promotorowego. Aktywacja transkrypcji danego genu jest zależna od integralności zdimeryzowanych domen b-HLH-LZ USF z regionem DNA. Procesy fosforylacji i metylacji mogą regulować zarówno ekspresję samego genu USF1, jak i zdolność wiązania się białkowego czynnika transkrypcyjnego z regionem promotora genu docelowego. Czynnik transkrypcyjny USF1 reguluje ekspresję istotnych genów zaangażowanych m.in.
\end{abstract}

w cykl komórkowy, proliferację komórkową, procesy starzenia komórkowego, reakcję na stres, odpowiedź immunologiczną organizmu, procesy nowotworzenia oraz w metabolizm węglowodanów i lipidów. Ponadto warianty polimorficzne genu USF1 mogą być związane m.in. z ponadnormatywnymi stężeniami wskaźników gospodarki lipidowej, glukozy, a także markerów specyficznych dla procesów kancerogenezy. Spośród zbadanych polimorfizmów genu USF1 można wyróżnić grupę wariantów genetycznych, którym przypisuje się również związek z czynnikami ryzyka predysponującymi do wystąpienia zdarzeń sercowo-naczyniowych. USF1 jest jednym z głównych czynników zaangażowanych w patomechanizm jednostek chorobowych takich jak: choroba wieńcowa, cukrzyca typu II, zespół metaboliczny oraz rodzinna hiperlipidemia mieszana.

Słowa kluczowe: USF1; polimorfizm; choroba wieńcowa; cukrzyca typu II; nowotwory.

\section{WSTĘP}

Gen USF1 (upstream stimulatory factor 1) koduje polipeptyd USF1 należący do rodziny powszechnie eksprymowanych czynników transkrypcyjnych, których podstawę strukturalną tworzą domeny helisa-pętla-helisa (helix-loop-helix - HLH) z zamkiem leucynowym (leucine zipper - LZ) [1]. USF1 jest podjednostką dimerycznego czynnika transkrypcyjnego USF [2]. Białko USF1 może tworzyć homodimery lub heterodimery z polipeptydem USF2. W takiej formie odpowiada za regulację ekspresji wielu genów cechujących się obecnością motywu E-box w obrębie regionu promotorowego. Czynnik transkrypcyjny USF1 jest zaangażowany w liczne procesy zachodzące zarówno lokalnie, na poziomie komórki, takie jak proliferacja komórkowa oraz cykl komórkowy, jak i globalnie, na poziomie całego organizmu, takie jak odpowiedź immunologiczna, reakcja na stres, a także koordynacja licznych szlaków metabolicznych, w tym lipidów i węglowodanów. USF1 jest również jednym z kluczowych czynników zaangażowanych w patomechanizm jednostek chorobowych takich jak: rodzinna hiperlipidemia mieszana (familial combined hyperlipidemia - FCHL), miażdżyca, choroba wieńcowa, cukrzyca typu II oraz zespół metaboliczny. Z tego 
względu, zarówno gen, jak i białko USF1, stały się przedmiotem zainteresowań wielu badaczy.

\section{BUDOWA BIAŁKA USF1 I GENU USF1}

Gen USF1 (ryc. 1) [3] o całkowitej długości 9549 par zasad zlokalizowany jest na ramieniu długim chromosomu 1 (1q22-23). W swej strukturze zawiera 11 egzonów. USF1 koduje białkowy czynnik transkrypcyjny o masie $43 \mathrm{kDa}[1,2,4]$.

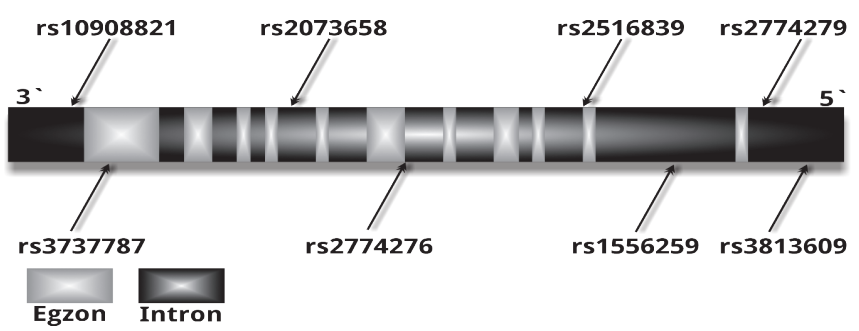

RYCINA 1. Struktura genu USF1 z najczęściej omawianymi w literaturze miejscami polimorficznymi [3]

Białko USF1 charakteryzują wysoce konserwatywne domeny helisa-pętla-helisa oraz motyw zamka leucynowego [5]. Domeny HLH i LZ, będące amfipatycznymi $\alpha$-helisami, współuczestniczą w procesie parowania dimerów USF1-USF2 [6, 7]. Ze względu na specyficzność rozpoznawania interakcje między polipeptydami zostają ograniczone do oddziaływań pomiędzy domenami helisa-pętla-helisa (b-HLH) oraz pomiędzy domeną helisa-pętla-helisa a domeną zamka leucynowego (b-HLH-LZ) [8, 9]. Powstałe kompleksy o charakterze homodimerów lub heterodimerów rozpoznają docelową sekwencję DNA i przy współudziale dodatkowych czynników transkrypcyjnych dochodzi do aktywacji bądź wyciszenia procesu transkrypcji. Rdzeniowa sekwencja E-box genu docelowego składa się z 6 nukleotydów CANNTG, z czego centralne nukleotydy (NN) to najczęściej GC lub CG. Konserwatyzm tych sekwencji jest istotny ze względu na różnice w powinowactwie łączenia się określonych czynników transkrypcyjnych z motywem rdzeniowym. Na wiązanie czynników z sekwencją E-box wpływa sam promotor, modyfikując zdolność ich przyłączania. Ponadto kinazy A, C oraz białko p38 mogą fosforylować USF1, zwiększając zdolności wiązania tego czynnika z motywem E-box genu docelowego [2]. W przeciwieństwie do wcześniej wymienionych kinaz kinaza 3-fosfatydyloinozytolu (phosphatidyl inositol 3-kinase - $\mathrm{PI} 3 \mathrm{~K}$ ) katalizuje fosforylację dimerów i tym samym ogranicza wiązanie czynnika z sekwencją promotora [10]. Natężenie ekspresji samego genu USF1 również może podlegać modyfikacjom. Procesem znacząco obniżającym ekspresję USF1 jest metylacja dinukleotydów zajmujących centralnie miejsce sekwencji E-box, na skutek czego powstają tzw. wyspy CpG (CACpGTG) [11].

Aktywacja transkrypcji danego genu wymaga integralności zdimeryzowanych domen b-HLH-LZ dimeru USF z regionem DNA. Na skutek interakcji białka USF1 z transkrypcyjnym kompleksem miejsca promotorowego USF wiąże się z motywem E-box, umożliwiając stymulację transkrypcji [12]. Na tym etapie za rozpoznanie podstawowego promotora i jego oddziaływanie z USF1 odpowiada kompleks pre-inicjujący, składający się m.in. z czynnika TFIID (transcription factor II D) zawierającego podjednostkę TBP (TATA-binding protein). W przypadku braku bloku TATA w obrębie miejsca promotorowego USF1 może przyłączać się bezpośrednio do elementu inicjatorowego Inr (initiator element). Istotną rolę regulatora transkrypcji pełni czynnik TFII-I (transcription factor II-I) mogący niezależnie wiązać się zarówno z bogatym w pirymidyny inicjatorem Inr, jak i regionem E-box rozpoznawanym przez USF1 [13]. TFII-I stymuluje wiązanie USF1 z obydwoma elementami promotora i współdziała z nim synergistycznie w aktywacji procesu transkrypcji. Ostatecznie aktywność enzymów takich jak acetylaza histonowa PCAF (histone acetyltransferase) oraz metylaza histonowa SET7/9 (histone methyltransferase) pozwala na przemodelowanie struktury chromatyny, zapoczątkowując proces transkrypcji [2]. USF1 zaangażowany jest w transkrypcję m.in. genów dla apolipoproteiny AII [14], apolipoproteiny CIII [15] i apolipoproteiny A5 [10], a także lipazy wątrobowej [16], glukokinazy [17] oraz angiotensynogenu [18].

\section{ZWIĄZEK WARIANTÓW POLIMORFIZMÓW USF1 Z CHOROBĄ WIEŃCOWĄ}

Czynnik transkrypcyjny USF1 reguluje ekspresję istotnych genów zaangażowanych m.in. w procesy starzenia komórkowego, reakcję na stres, procesy nowotworzenia oraz w metabolizm węglowodanów i lipidów. Wiele genów poddawanych kontroli USF1 wykazuje związek z molekularną patogenezą chorób sercowo-naczyniowych [19]. Gen USF1 jest ważnym kandydatem chorób o podłożu miażdżycowym, w tym choroby wieńcowej, ze względu na udział w regulacji ekspresji genów dla apolipoprotein i enzymów istotnych dla metabolizmu lipidów [20]. Badania, których celem było poszukiwanie związków pomiędzy wariantami polimorficznymi genu USF1 a chorobą wieńcową, dały jednak niejednoznaczne wyniki.

Komulainen i wsp. [19] stwierdzili zależny od płci związek polimorfizmu rs2774279 z chorobą wieńcową w populacji fińskiej. Nosicielki allelu G były 4-krotnie bardziej predysponowane do rozwoju choroby wieńcowej ( $\mathrm{HR}=4,01 ; 95 \% \mathrm{CI}$ : 1,30-12,39; $\mathrm{p}=$ 0,02) oraz ponad 4-krotnie bardziej narażone na śmierć (HR = 4,43; 95\% CI: 1,58-12,40; p = 0,005) względem nosicielek allelu A. Ponadto w tej samej grupie nosicielstwo allelu T polimorfizmu rs2073658 zwiększało ponad 2-krotnie ryzyko rozwoju choroby wieńcowej ( $\mathrm{HR}=2,02 ; 95 \% \mathrm{CI}$ : 1,16-3,53; $p=0,01$ ), a także ponad 2,5-krotnie ryzyko śmierci (HR = 2,52; 95\% CI: 1,46-4,35; p = 0,0009) w porównaniu do nosicielek allelu C. Można przypuszczać, że USF1 reguluje ekspresję genów zaangażowanych m.in. w metabolizm lipidów, mogących w określonych warunkach stanowić czynnik ryzyka rozwoju choroby wieńcowej. Ponadto USF1 prawdopodobnie wpływa także na ekspresję genów odpowiedzialnych za procesy starzenia komórkowego, które bezpośrednio przyczyniają 
się do dysfunkcji organizmu i tym samym do zwiększenia ryzyka zgonu z przyczyn odmiennych niż zdarzenia sercowo-naczyniowe. Reiner i wsp. [21] nie wykazali związku wybranych wariantów polimorficznych USF1 (rs2516837, rs1556259, rs2516838, rs2774276, rs3737787) z chorobą wieńcową zdiagnozowaną u 1546 przebadanych probantów ( $p>0,05)$. Wu i wsp. [22], badając 654 pacjentów z potwierdzoną angiograficznie chorobą wieńcową, również nie wykazali istotnego związku polimorfizmu rs2516839 z chorobami sercowo-naczyniowymi $(p>0,05)$ w populacji chińskiej. Odmienne wyniki otrzymali Kristiansson i wsp. [23], analizując wpływ polimorfizmu rs2516839 na wykształcenie fenotypu choroby wieńcowej. Na podstawie badań autopsyjnych 700 mężczyzn populacji fińskiej autorzy dowiedli, że genotyp TT vs CC polimorfizmu rs2516839 predysponuje niemal 3-krotnie bardziej do zwapnień tętnic wieńcowych (OR = 2,80; 95\% CI: 1,80-4,35; p < 0,001), a także wykazuje związek ze stopniem zaawansowania blaszki miażdżycowej (OR = 1,82; 95\% CI: 1,11-2,98; $\mathrm{p}=0,02$ ).

\section{ZWIAZZEK WARIANTÓW POLIMORFICZNYCH USF1 Z CZYNNIKAMI RYZYKA CHORÓB SERCOWO-NACZYNIOWYCH}

Spośród stwierdzonych polimorfizmów genu USF1 można wyróżnić grupę wariantów genetycznych, którym przypisuje się szczególny związek z czynnikami ryzyka zdarzeń sercowo-naczyniowych, co potwierdzają liczne badania eksperymentalne.

Jednym z czynników ryzyka choroby wieńcowej jest rodzinna hiperlipidemia mieszana. Na podstawie analizy sprzężeń FCHL zmapowano do locus 1q21-23, co w konsekwencji doprowadziło do zidentyfikowania czynnika USF1, który bezpośrednio wpływa na profil lipidowy [24]. FCHL rozpoznawana jest u niemal $20 \%$ pacjentów ze stwierdzoną chorobą wieńcową [20]. Charakteryzuje się wzrostem stężenia lipoprotein niskiej gęstości (low density lipoprotein - LDL) i triacylogliceroli (triglycerides - TG) oraz zazwyczaj obniżeniem poziomu lipoprotein wysokiej gęstości (high density lipoprotein - HDL) [25].

Van der Vleuten i wsp. [26], badając 36 holenderskich rodzin, wykazali niezależny od płci związek polimorfizmów rs3737787 $(p=0,08)$ oraz rs2073658 $(p=0,07)$ z rodzinną hiperlipidemią mieszaną. Jednak otrzymany wynik wydaje się niejednoznaczny, mając na uwadze fakt, że przeprowadzona analiza genomu nie ujawniła locus USF1 jako głównego genu predysponującego populację holenderską do FCHL. Na podstawie podobnej pod względem grupy etnicznej analizy Lee i wsp. [20] wykazali związek wariantu polimorficznego rs3737787 z FCHL oraz poziomem lipidów. Stwierdzono istotny związek nosicielstwa allelu C polimorfizmu rs3737787 z FCHL, ponadnormatywnym stężeniem TG, cholesterolu całkowitego (total cholesterol TC) i apolipoproteiny B ( $p=0,02-0,006)$ u mężczyzn. Otrzymane wyniki potwierdzono zarówno w podgrupie badanych z rodzinną hipercholesterolemią mieszaną, jak i w podgrupie ze stwierdzoną angiograficznie chorobą wieńcową. Ponadto wśród mężczyzn z chorobą wieńcową stwierdzono związek nosicielstwa allelu C ze stężeniem TG $(\mathrm{p}=0,03)$ względem nosicielstwa allelu T. Natomiast w grupie kobiet z chorobą wieńcową wykazano związek nosicielstwa allelu T ze stężeniem TG $(p=0,0005)$ oraz wskaźnikiem masy ciała - BMI ( $p=0,00004)$ w porównaniu z nosicielkami allelu C. Na różnice w wynikach prac badawczych Van der Vleutena i wsp. [26] oraz Lee i wsp. [20] prawdopodobnie mógł wpłynąć sam charakter FCHL jako jednostki chorobowej o złożonym i różnorodnym podłożu. Możliwe, że wpływ czynników środowiskowych, czy też różnice w samym kryterium doboru i kwalifikacji grup badanych, spowodowały rozbieżności w otrzymanych wynikach. Reiner i wsp. [21] poddali analizie dwie grupy Europejczyków pochodzenia amerykańskiego w przedziale wiekowym 18-30 lat oraz 65-98 lat. Dla badanych z niższego przedziału wiekowego wykazano związek allelu T polimorfizmu rs3737787 z obniżonym stężeniem cholesterolu całkowitego oraz cholesterolu frakcji LDL ( $p=0,02, p=0,012)$ względem nosicielstwa allelu C, co nie zostało potwierdzone w starszej wiekowo grupie. Autorzy sugerują, że istnieje związek między wariantami polimorficznymi USF1 a fenotypem ściśle zależnym od wieku. Osoby starsze wykazywały mało znaczący związek ze stężeniem lipidów i zdarzeniami sercowo-naczyniowymi, jednak przejawiały zwiększone ryzyko śmierci. Rezultat badań prawdopodobnie wynika z fenotypu prozapalnego mającego związek z wiekiem pacjenta [21]. Z kolei Pajukanta i wsp. [27] przeprowadzili badania z udziałem 60 fińskich rodzin spełniających kryteria fenotypu FCHL. Zgenotypowano 3 polimorfizmy USF1 rs3737787, rs2073658 oraz rs2516839. Wariant genetyczny rs2516839 jako jedyny nie wykazał związku ze stężeniem TG i FCHL. Dla pozostałych 2 polimorfizmów (rs3737787, rs2073658) wykazano związek z FCHL ( p = 0,00002), szczególnie w grupie mężczyzn z ponadnormatywnym poziomem triacylogliceroli ( $p=0,0000009$ ) [27]. Tych wyników w tej samej populacji nie potwierdzili Komulainen i wsp. [19]. Nie stwierdzono związku polimorfizmu rs2073658 z czynnikami ryzyka predysponującymi do rozwoju choroby wieńcowej. Natomiast analiza wpływu polimorfizmu rs2516839 wykazała związek nosicielstwa allelu C z ponadnormatywnym stężeniem TC $(\mathrm{p}=0,001)$ względem nosicielstwa allelu T u mężczyzn. Zaobserwowano również związek polimorfizmu rs2516839 z podwyższonym BMI wśród kobiet będących nosicielkami allelu C $(\mathrm{p}=0,006)$ względem nosicielek allelu T. Widoczne rozbieżności w wynikach badań, które uzyskali Pajukanta i wsp. [27] oraz Komulainen i wsp. [19], prawdopodobnie wnikają z różnic w obrębie samych grup badanych, uwzględniając wpływy środowiskowe i tryb życia. Możliwe, że podgrupa mężczyzn, wykazana przez Pajukanta i wsp. [27], jako jedyna mająca związek ze stężeniem TG, była szczególnie narażona na zewnętrzne czynniki obciążające. Odmienne wyniki otrzymali Laurila i wsp. [28] w badaniach przeprowadzonych z udziałem 139 australijskich rodzin. Stwierdzono związek allelu T rs2516839 z ponadnormatywnym stężeniem triacylogliceroli $(\mathrm{p}=0,0078)$ i obniżonym stężeniem cholesterolu frakcji HDL ( $\mathrm{p}=0,01)$ wśród badanych z chorobą wieńcową. Powyższe wyniki badań nie zostały potwierdzone w populacji chińskiej. Wu i wsp. [22] nie wykazali związku polimorfizmu rs2516839 z czynnikami ryzyka choroby wieńcowej. 
Jednakże poziom TC, LDL i apolipoproteiny B był wyraźnie niższy u pacjentów z genotypem GG vs AG+AA [22]. Badacze sugerują, że polimorfizm rs2516839 może wykazywać ochronną rolę względem dyslipidemii i w następstwie rozwoju choroby wieńcowej w obrębie analizowanej populacji chińskiej. Grupa badana składała się z 654 pacjentów z potwierdzoną angiograficznie chorobą wieńcową. Powodem różnic między wynikami badań Wu i wsp. [22] a pozostałych badaczy prawdopodobnie może być odmienne tło etniczne badanych osób. Natomiast w populacji polskiej Niemiec i wsp. [29] dowiedli, że genotypy USF1 mogą modyfikować stężenie triacylogliceroli i ryzyko rozwoju choroby wieńcowej w odpowiedzi na palenie tytoniu. Analizując genetyczne i środowiskowe czynniki ryzyka, ujawniono, że nosicielstwo allelu C polimorfizmu rs2516839 zwiększa ryzyko choroby wieńcowej u osób palących tytoń względem homozygot TT (model multiplikatywny; SIM = 2,69; 95\% CI: 1,21-6,01; p = 0,015). Wykazano także związek pomiędzy paleniem tytoniu a wzrostem stężenia TG dodatnio zależny od liczby kopii allelu C [29]. Ponadto ujawniono, że genotyp CC jest związany z ponadnormatywnym stężeniem TG $(\mathrm{OR}=1,81$; 95\% CI: 1,16-2,82; p = 0,008) w odróżnieniu do genotypu TT związanego z obniżonym stężeniem TG $(\mathrm{OR}=0,58$; $95 \% \mathrm{CI}$ : $0,32-0,86 ; p=0,007)$. Interakcje wariantu polimorficznego rs2516839 z ponadnormatywnymi stężeniami triacylogliceroli w osoczu mogą modyfikować reakcję organizmu na stres, jednakże mechanizm omawianej interakcji wymaga dalszych wyjaśnień i analiz.

Związek rzadziej omawianych w literaturze polimorfizmów genu USF1 z czynnikami ryzyka predysponującymi do rozwoju choroby wieńcowej został przedstawiony w tabeli 1.

\section{ZWIĄZEK WARIANTÓW POLIMORFICZNYCH USF1 Z CUKRZYCA}

Ze względu na zaangażowanie USF1 w regulację licznych szlaków metabolicznych, w tym węglowodanów, gen USF1 może odgrywać kluczową rolę w kształtowaniu ryzyka rozwoju cukrzycy typu II.

Gibson i wsp. [1] w badaniach przeprowadzonych na populacji francuskiej nie wykazali związku polimorfizmów genu USF1 (rs2516837, rs1556259, rs2516838, rs2073653, rs2774276, rs2516841, rs2073658, rs3737787) z cukrzycą typu II ( p > 0,05). Podobny wynik otrzymali Meex i wsp. [24], wyodrębniając grupę badaną spośród populacji holenderskiej. Nie stwierdzono istotnego związku polimorfizmu rs3737787 z cukrzycą typu II, natomiast wykazano, że nosicielstwo allelu G rs2073658 nieznacznie zwiększa predyspozycje do rozwoju cukrzycy $(\mathrm{OR}=1,25 ; 95 \% \mathrm{CI}: 1,04-1,48 ; \mathrm{p}=$ 0,018) w porównaniu $\mathrm{z}$ homozygotami AA. Wyników tych nie potwierdzili Holzapfel i wsp. [3] w populacji niemieckiej. Grupę badaną stanowiło 498 probantów ze zdiagnozowaną cukrzycą typu II, a grupa kontrolna składała się ze 1569 osób nieprzejawiających fenotypu choroby. Badacze wykazali ochronną rolę polimorfizmu rs3737787. Heterozygotyczne kobiety (AG) przejawiały niemal 2-krotnie mniejsze ryzyko rozwoju cukrzycy typu II (OR = 0,57; 95\% CI: $0,38-0,87 ; p=0,008$ ) względem homozygotycznych kobiet (GG). Niespójności w wynikach prawdopodobnie wynikają z różnic etnicznych badanych grup. Natomiast Ng i wsp. [31] przeprowadzili analizę 179 rodzin i 1383 pacjentów populacji chińskiej hospitalizowanych ze zdiagnozowaną cukrzycą typu II i/lub zespołem metabolicznym. Badacze stwierdzili związek allelu C polimorfizmu rs3737787 ze wzrostem ryzyka rozwoju cukrzycy typu II w obrębie badanych rodzin (OR = 1,55; 95\% CI: 1,06-2,26; $p=0,024$ ), jednocześnie nie wykazując go dla osób hospitalizowanych ze zdiagnozowaną cukrzycą. Możliwe, że zaistniałe rozbieżności w wynikach badań Ng i wsp. [31] oraz pozostałych badaczy wynikają z różnic w kryterium włączenia do grupy badanej, a także heterogenności klinicznej i etnicznej probantów.

\section{ZWIĄZEK USF1 Z NOWOTWORAMI}

Kancerogeneza to proces wieloetapowy i wieloczynnikowy. W rozwoju oraz ostatecznym ujawnieniu fenotypu choroby istotne znaczenie mają zarówno wpływy środowiskowe, jak i podłoże genetyczne. Białko USF1 reguluje ekspresję wielu genów zaangażowanych w procesy nowotworzenia, m.in. genu MVP (major vault protein), który koduje polipeptyd odpowiedzialny za transfer między jądrem komórkowym a cytoplazmą [32, 33]. Możliwe, że USF1, wpływając na ekspresję genu $M V P$, pośrednio warunkuje wykształcenie się wielolekoopornego fenotypu przez obniżanie wewnątrzkomórkowego stężenia cząsteczek terapeutyków lub też zmianę ich rozmieszczenia między poszczególnymi przedziałami wewnątrzkomórkowymi [34]. Ikeda i wsp. [33] w pracy badawczej bazowali na ludzkiej linii komórkowej SW620 raka jelita

TABELA 1. Wpływ pozostałych analizowanych wariantów polimorficznych genu USF1 na czynniki ryzyka choroby wieńcowej

\begin{tabular}{|c|c|c|c|c|c|c|}
\hline Autorzy & Rok & Polimorfizm & Allel & Związek z czynnikami ryzyka & Wyniki & Populacja \\
\hline \multirow[t]{2}{*}{$\begin{array}{l}\text { Putt i wsp. } \\
\text { [30] }\end{array}$} & \multirow[t]{2}{*}{2004} & rs2073653 & Allel G + BMI & $\begin{array}{l}\text { wzajemny wpływ nosicielstwa alellu G i BMI na stężenie } \\
\text { LDL w osoczu u osób z chorobą wieńcową }\end{array}$ & $p=0,0002$ & $\begin{array}{l}\text { grupa badana } \\
\text { zebrana }\end{array}$ \\
\hline & & rs2073655 & Allel T + BMI & $\begin{array}{l}\text { wzajemny wpływ nosicielstwa alellu T i BMI na stężenie } \\
\text { glukozy w osoczu u osób z chorobą wieńcową }\end{array}$ & $p=0,0002$ & $\begin{array}{l}\text { z } 11 \text { krajów } \\
\text { europejskich }\end{array}$ \\
\hline \multirow{2}{*}{$\begin{array}{l}\text { Reiner } \\
\text { i wsp. [21] }\end{array}$} & \multirow[t]{2}{*}{2007} & rs2516837 & Allel T & podwyższone stężenie cholesterolu LDL & $p=0,016$ & \multirow{2}{*}{$\begin{array}{l}\text { Europejczycy } \\
\text { pochodzenia } \\
\text { amerykańskiego }\end{array}$} \\
\hline & & rs2073655 & Allel T & $\begin{array}{l}\text { ryzyko śmiertelności z przyczyn odmiennych niż ze strony } \\
\text { układu sercowo-naczyniowego zależne od liczby kopii } \\
\text { allelu T }\end{array}$ & $p=0,004$ & \\
\hline $\begin{array}{l}\text { Laurila } \\
\text { i wsp. [28] }\end{array}$ & 2010 & rs1556259 & Allel A vs Allel G & podwyższone stężenie TG & $p=0,0022$ & Australijczycy \\
\hline
\end{tabular}


grubego. Przeprowadzona analiza wykazała, że wprowadzenie dwuniciowych cząsteczek siRNA, mających za zadanie wyciszenie ekspresji genu USF1, powoduje spadek ekspresji genu MVP. Wynik ten może świadczyć o regulatorowej funkcji USF1 względem ekspresji komórkowo-specyficznych białek MVP w liniach komórkowych podlegających procesom kancerogenezy [33]. Ponadto Chen i wsp. [35] przebadali 57 pacjentów ze zdiagnozowanym nowotworem wątrobowokomórkowym, którzy zostali poddani resekcji chirurgicznej. W tkance zmienionej nowotworowo wykazano wzmożoną aktywność heparanazy, co wiąże się bezpośrednio z możliwością aktywowania patologicznych procesów takich jak m.in. angiogeneza i metastaza. Enzym heparanaza kodowany jest przez gen HPSE (Heparanase). Promotor HPSE zawiera w swej strukturze 6 motywów E-box rozpoznawanych przez czynnik transkrypcyjny USF. Chen i wsp. stwierdzili wzrost ekspresji genów z rodziny $U S F$, w tym $U S F 1$ i jego korelację z ekspresją heparanazy. Wykazano, że USF1 może regulować ekspresję HPSE, co ma istotne znaczenie w kontekście możliwości zastosowania USF1 jako markera świadczącego o metastazie [35]. Zhao i wsp. [36] przeprowadzili badania 94 pacjentów populacji chińskiej ze stwierdzonym nowotworem wątrobowokomórkowym. Na podstawie analizy wykazano, że nosicielstwo allelu A vs G polimorfizmu rs2516839 USF1 warunkuje wzrost ryzyka zachorowania na nowotwór wątrobowokomórkowy (OR = 2,09; 95\% CI: 1,35-3,23; p < 0,001). Ponadto genotypy AA vs GG (OR = 3,15; 95\% CI: 1,44-6,87; $\mathrm{p}=0,003)$, AA vs GG+GA (OR = 2,96; 95\% CI: 1,40-6,26; $\mathrm{p}=0,004)$ oraz GA+AA vs AA (OR = 1,85; 95\% CI: 1,04-3,30; $p=0,034)$ zwiększają predyspozycje do rozwoju nowotworu wątrobowokomórkowego w populacji chińskiej [36]. Yuan i wsp. [37] ujawnili wpływ polimorfizmów rs2516838, rs3737787 i rs2516839 na ryzyko rozwoju nowotworu brodawkowatego tarczycy (papillary thyroid cancer - PTC) w populacji chińskiej. Grupę badaną stanowiło 334 pacjentów ze zdiagnozowanym PTC oraz 186 pacjentów z łagodnymi guzami. Otrzymane wyniki wskazują na funkcję ochronną zarówno allelu C vs G (OR = 0,031; 95\% CI: 0,56-0,97; $\mathrm{p}=0,031)$, jak i genotypów GC+GG vs CC polimorfizmu rs2516838 $(\mathrm{OR}=0,71 ; 95 \%$ CI: 0,52-0,97; p = 0,033) zmniejszającą ryzyko rozwoju PTC. Natomiast genotypy CT+TT vs CC polimorfizmu rs3737787 (OR = 1,55; 95\% CI: 1,09-2,02; $\mathrm{p}=0$,001) oraz GA+AA vs GG polimorfizmu rs2516839 (OR = 1,77; 95\% CI: 1,31-2,38; $\mathrm{p}<0,001)$ mogą stanowić czynnik ryzyka rozwoju nowotworu brodawkowatego tarczycy.

\section{PODSUMOWANIE}

Dalsze badania nad wpływem wariantów polimorficznych USF1 jako regulatora ekspresji genów zaangażowanych w rozmaite procesy zachodzące w ludzkim organizmie mogą pozwolić na lepsze zrozumienie patomechanizmów wielu jednostek chorobowych. Natomiast dokładniejsze poznanie wzajemnych interakcji zachodzących między czynnikami środowiskowymi i czynnikami genetycznymi może w przyszłości skutkować właściwszym doborem leków oraz metod terapeutycznych.

\section{PIŚMIENNICTWO}

1. Gibson F, Hercberg S, Froguel P. Common polymorphisms in the USF1 gene are not associated with type 2 diabetes in French Caucasians. Diabetes 2005;54(10):3040-2.

2. Corre S, Galibert MD. Upstream stimulating factors: highly versatile stressresponsive transcription factors. Pigment Cell Res 2005;18(5):337-48.

3. Holzapfel C, Baumert J, Grallert H, Müller AM, Thorand B, Khuseyinova N, et al. Genetic variants in the USF1 gene are associated with low-density lipoprotein cholesterol levels and incident type 2 diabetes mellitus in women: results from the MONICA/KORA Augsburg case-cohort study, 1984-2002. Eur J Endocrinol 2008;159(4):407-16.

4. Choquette AC, Bouchard L, Houde A, Bouchard C, Pérusse L, Vohl MC. Associations between USF1 gene variants and cardiovascular risk factors in the Quebec Family Study. Clin Genet 2007;71(3):245-53.

5. Sha M, Ferré-D’Amaré AR, Burley SK, Goss DJ. Anti-cooperative biphasic equilibrium binding of transcription factor upstream stimulatory factor to its cognate DNA monitored by protein fluorescence changes. J Biol Chem 1995;270(33):19325-9.

6. Sirito M, Walker S, Lin Q, Kozlowski MT, Klein WH, Sawadogo M. Members of the USF family of helix-loop-helix proteins bind DNA as homo- as well as heterodimers. Gene Expr 1992;2(3):231-40.

7. Sirito M, Lin Q, Maity T, Sawadogo M. Ubiquitous expression of the 43and 44-kDa forms of transcription factor USF in mammalian cells. Nucleic Acids Res 1994;22(3):427-33.

8. Baxevanis AD, Vinson CR. Interactions of coiled coils in transcription factors: where is the specificity? Curr Opin Genet Dev 1993;3(2):278-85.

9. Ciarapica R, Rosati J, Cesareni G, Nasi S. Molecular recognition in helixloop-helix and helix-loop-helix-leucine zipper domains. Design of repertoires and selection of high affinity ligands for natural proteins. J Biol Chem 2003;278(14):12182-90.

10. Nowak M, Helleboid-Chapman A, Jakel H, Martin G, Duran-Sandoval D, Staels B, et al. Insulin-mediated down-regulation of apolipoprotein A5 gene expression through the phosphatidylinositol 3-kinase pathway: role of upstream stimulatory factor. Mol Cell Biol 2005;25(4):1537-48.

11. Prendergast GC, Ziff EB. Methylation-sensitive sequence-specific DNA binding by the c-Myc basic region. Science 1991;251(4990):186-9.

12. Ferré-D'Amaré AR, Pognonec P, Roeder RG, Burley SK. Structure and function of the b/HLH/Z domain of USF. EMBO J 1994;13(1):180-9.

13. Roy AL, Meisterernst M, Pognonec P, Roeder RG. Cooperative interaction of an initiator-binding transcription initiation factor and the helix-loophelix activator USF. Nature 1991;354(6350):245-8.

14. Ribeiro A, Pastier D, Kardassis D, Chambaz J, Cardot P. Cooperative binding of upstream stimulatory factor and hepatic nuclear factor 4 drives the transcription of the human apolipoprotein A-II gene. J Biol Chem 1999;274(3):1216-25

15. Pastier D, Lacorte JM, Chambaz J, Cardot P, Ribeiro A. Two initiator-like elements are required for the combined activation of the human apolipoprotein C-III promoter by upstream stimulatory factor and hepatic nuclear factor-4. J Biol Chem 2002;277(17):15199-206.

16. Botma GJ, Verhoeven AJ, Jansen H. Hepatic lipase promoter activity is reduced by the $\mathrm{C}-480 \mathrm{~T}$ and $\mathrm{G}-216 \mathrm{~A}$ substitutions present in the common LIPC gene variant, and is increased by Upstream Stimulatory Factor. Atherosclerosis 2001;154(3):625-32.

17. Iynedjian PB. Identification of upstream stimulatory factor as activator of the liver promoter of the glucokinase gene. Biochem J 1998;333(Pt3): 705-12.

18. Yanai K, Saito T, Hirota K, Kobayashi H, Murakami K, Fukamizu A. Molecular variation of the human angiotensinogen core promoter element located between the TATA box and transcription initiation site affects its transcriptional activity. J Biol Chem 1997;272(48):30558-62.

19. Komulainen K, Alanne M, Auro K, Kilpikari R, Pajukanta P, Saarela J, et al. Risk alleles of USF1 gene predict cardiovascular disease of women in two prospective studies. PLoS Genet 2006;2(5):e69.

20. Lee JC, Weissglas-Volkov D, Kyttälä M, Sinsheimer JS, Jokiaho A, de Bruin TW, et al. USF1 contributes to high serum lipid levels in Dutch FCHL families and U.S. whites with coronary artery disease. Arterioscler Thromb Vasc Biol 2007;27(10):2222-7.

21. Reiner AP, Carlson CS, Jenny NS, Durda JP, Siscovick DS, Nickerson DA, et al. USF1 gene variants, cardiovascular risk, and mortality in European 
Americans: analysis of two US cohort studies. Arterioscler Thromb Vasc Biol 2007;27(12):2736-42.

22. Wu Ch, Gong Y, Zhu X. The Polymorphisms rs2516839 of USF1 and -173G/C of MIF were not associated with coronary artery disease but dyslipidemia in a Chinese Population. J Cardiovasc Dis Diagn 2014;2:6.

23. Kristiansson K, Ilveskoski E, Lehtimäki T, Peltonen L, Perola M, Karhunen PJ. Association analysis of allelic variants of USF1 in coronary atherosclerosis. Arterioscler Thromb Vasc Biol 2008;28(5):983-9. doi: 10.1161/ ATVBAHA.107.156463.

24. Meex SJ, van Vliet-Ostaptchouk JV, van der Kallen CJ, van Greevenbroek MM, Schalkwijk CG, Feskens EJ, et al. Upstream transcription factor 1 (USF1) in risk of type 2 diabetes: association study in 2000 Dutch Caucasians. Mol Genet Metab 2008;94(3):352-5.

25. Suviolahti E, Lilja HE, Pajukanta P. Unraveling the complex genetics of familial combined hyperlipidemia. Ann Med 2006;38(5):337-51.

26. Van der Vleuten GM, Isaacs A, Hijmans A, van Duijn CM, Stalenhoef AF, de Graaf J. The involvement of upstream stimulatory factor 1 in Dutch patients with familial combined hyperlipidemia. J Lipid Res 2007;48(1):193-200.

27. Pajukanta P, Lilja HE, Sinsheimer JS, Cantor RM, Lusis AJ, Gentile M, et al. Familial combined hyperlipidemia is associated with upstream transcription factor 1 (USF1). Nat Genet 2004;36(4):371-6.

28. Laurila PP, Naukkarinen J, Kristiansson K, Ripatti S, Kauttu T, Silander K, et al. Genetic association and interaction analysis of USF1 and APOA5 on lipid levels and atherosclerosis. Arterioscler Thromb Vasc Biol 2010;30(2):346-52.

29. Niemiec P, Nowak T, Iwanicki T, Gorczynska-Kosiorz S, Balcerzyk A, Krauze J, et al. The rs2516839 polymorphism of the USF1 gene may modulate serum triglyceride levels in response to cigarette smoking. Int J Mol Sci 2015;16(6):13203-16.
30. Putt W, Palmen J, Nicaud V, Tregouet DA, Tahri-Daizadeh N, Flavell DM, et al. Variation in USF1 shows haplotype effects, gene: gene and gene: environment associations with glucose and lipid parameters in the European Atherosclerosis Research Study II. Hum Mol Genet 2004;13(15): 1587-97.

31. Ng MC, Miyake K, So WY, Poon EW, Lam VK, Li JK, et al. The linkage and association of the gene encoding upstream stimulatory factor 1 with type 2 diabetes and metabolic syndrome in the Chinese population. Diabetologia 2005;48(10):2018-24

32. Pohl G, Suchomel RW, Stranzl T, Depisch D, Stiglbauer W, Filipits M, et al. Expression of the lung resistance protein in primary colorectal carcinomas. Anticancer Res 2001;21(1A):201-4.

33. Ikeda R, Nishizawa Y, Tajitsu Y, Minami K, Mataki H, Masuda S, et al. Regulation of major vault protein expression by upstream stimulating factor 1 in SW620 human colon cancer cells. Oncol Rep 2014;31(1): 197-201.

34. Popęda M, Płuciennik E, Bednarek AK. Proteins in cancer multidrug resistance. Postępy Hig Med Dośw 2014;68:616-32.

35. Chen B, Chen XP, Wu MS, Cui W, Zhong M. Expressions of heparanase and upstream stimulatory factor in hepatocellular carcinoma. Eur J Med Res 2014;19:45.

36. Zhao X, Wang T, Liu B, Wu Z, Yu S, Wang T. Significant association between upstream transcription factor 1 rs2516839 polymorphism and hepatocellular carcinoma risk: a case-control study. Tumour Biol 2015;36(4): 2551-8.

37. Yuan Q, Bu Q, Li G, Zhang J, Cui T, Zhu R, et al. Association between single nucleotide polymorphisms of upstream transcription factor 1 (USF1) and susceptibility to papillary thyroid cancer. Clin Endocrinol (Oxf) 2016;84(4):564-70. doi: 10.1111/cen.12832. 